\title{
ZWINNE DOSTOSOWANIA PRZEDSIĘBIORSTW NA RYNKACH Z OKAZJONALNA PRZEWAGĄ KONKURENCYJNĄ
}

\section{WPROWADZENIE}

Konkurencyjność i pozycja konkurencyjna przedsiębiorstwa to pojęcia powszechnie stosowane $\mathrm{w}$ opracowaniach $\mathrm{z}$ zakresu ekonomii i nauk o zarządzaniu. Konkurowanie zwykle rozumie się jako proces rywalizacji przedsiębiorstw na rynkach, na których stawką jest pozyskanie klientów, mierzone tzw. udziałem w rynku i zwrotem na użytkowanych czynnikach produkcji. Procesy konkurowania determinują biznesowe sukcesy i porażki przedsiębiorstw. Racjonalna strategia konkurowania umożliwia przedsiębiorstwu zajęcie silnej pozycji na rynku albo rynkach, na których prowadzi ono działalność gospodarczą $^{1}$. Nie powinno zatem dziwić, że menedżerowie najwyższych szczebli poszukują odpowiedzi na pytanie, w jaki sposób zapewnić swoim przedsiębiorstwom przewagę konkurencyjną nad biznesowymi rywalami. Przewagę tę najczęściej się definiuje jako sytuację, w której przedsiębiorstwo osiaga handlową dominację nad rynkowymi rywalami, oferując klientom lepszą wartość, jakość lub serwis przez politykę niskich cen albo wyróżnienia swej oferty, nadając jej atrybuty najtrafniej dostosowane do oczekiwań klientów².

Odpowiedzi na to pytanie są jednak różne w odmiennych sytuacjach. Uwarunkowania konkurowania na różnych rynkach nie muszą bowiem pozostawać takimi samymi oraz wraz z upływem czasu uwarunkowania te moga ewoluować. Inaczej kształtuje się pozycję konkurencyjną w warunkach trwałej przewagi konkurencyjnej, a inaczej w warunkach bardzo labilnej przewagi konkurencyjnej. Uwarunkowania konkurowania mogą być zatem postrzegane jako determinanta skuteczności dostosowania sposobu zarządzania przedsiębiorstwem.

Mając to na uwadze, za główny cel niniejszego opracowania przyjmuje się, po pierwsze, identyfikację i charakterystykę relacji między typem uwarunkowań konkurowania a pożądanym dostosowaniem procesu zarządzania przedsiębiorstwem oraz po drugie, szczegółowy opis współczesnych uwarunkowań

${ }^{1}$ M. Porter, Przewaga konkurencyjna. Osiaganie i utrzymywanie lepszych wyników, Wydawnictwo Helion, Gliwice 2006, s. 27.

2 J. Sutherland, D. Canwell, Key Concepts in Strategic Management, Palgrave Macmillan, New York 2004, s. 30. 
konkurowania i na tym tle wskazanie najlepiej dostosowanego do nich sposobu zarządzania przedsiębiorstwem. Całość rozważań jest ilustrowana wybranymi przypadkami konkretnych przedsiębiorstw (jest to zastosowanie częstej w naukach o zarządzaniu metody egzemplifikacji empirycznej).

Logika konstrukcji artykułu polega na prezentacji w pierwszej kolejności podstawy teoretycznej $\mathrm{w}$ formie do pewnego stopnia historycznego przegladu istniejaccych koncepcji przewagi konkurencyjnej z punktu widzenia zarządzania strategicznego przedsiębiorstwem. Następnie zaprezentowane są egzemplifikacje empiryczne na podstawie przypadków firm Apple i Nokia, które pokazuja, jak zmieniały się uwarunkowania i źródła przewagi konkurencyjnej $\mathrm{w}$ praktyce biznesu w ostatnich latach. Wreszcie, część trzecia zawiera rekonstrukcję i interpretację koncepcji zwinnego przedsiębiorstwa, jako idei opisującej i wyjaśniającej współczesne zagadnienia przewagi konkurencyjnej.

\section{UWARUNKOWANIA KONKUROWANIA I ZARZĄDZANIE STRATEGICZNE}

W zależności od okoliczności determinujących trwałość przewagi konkurencyjnej poglądy co do jej charakteru są zróżnicowane. To zróżnicowanie prezentuje tabela 1 .

Jeśli przyjąć, że ewolucja przewagi konkurencyjnej w rozmaitych branżach przebiega od trwałej, przez stabilna, potem tymczasowa, aż po okazjonalna, to można tę ewolucję ogólnie określić jako przechodzenie od porządku do niepewności ${ }^{3}$. Pierwszy wyróżniony typ uwarunkowań konkurencyjnych tworzy możliwość wypracowania trwałej przewagi konkurencyjnej. Wynika ona z zajęcia pozycji lidera kosztowego albo lidera funkcjonalności i polega na znalezieniu takiego rynku, do którego dostęp dla konkurentów jest trudny. Zasadniczym zadaniem staje się obrona tej trudności przez piętrzenie barier wejścia. Szczegółowa charakterystyka tej odmiany przewagi konkurencyjnej przedstawia kolumna pierwsza tabeli 1 .

Pozycja lidera kosztowego wymaga podjęcia działań zmierzających do minimalizacji całkowitych kosztów działalności gospodarczej. Jest to możliwe, jeśli menedżerowie przedsiębiorstwa potrafią maksymalnie wykorzystać efekt doświadczenia (nazywany też efektem krzywej doświadczenia). W przedsiębiorstwie nastawionym na zajęcie pozycji lidera kosztowego kluczowe jest dażenie do wywalczenia jak największego udziału w rynku w jak najkrótszym odcinku czasu. Skutek oczywiście jest taki, że menedżerowie przedsiębiorstw koncentrują uwagę na masowych rynkach, na których realizują ideę masowego marketingu. To dążenie, według Williama Abernathy'ego i Kennetha Wayne'a, doprowadza zwykle do redukowania zdolności do wprowadzania innowacji i reagowania na zachowania konkurentów ${ }^{4}$.

${ }^{3}$ S. Brown, K. Eisenhardt, Competing on the Edge: Strategy as Structured Chaos, Press, Boston 1998, s. 8.

${ }^{4}$ P. Ghemawat, Competition and Business Strategy in Historical Perspective, „Business History Review" 76, 2002, Spring, s. 49-50. 


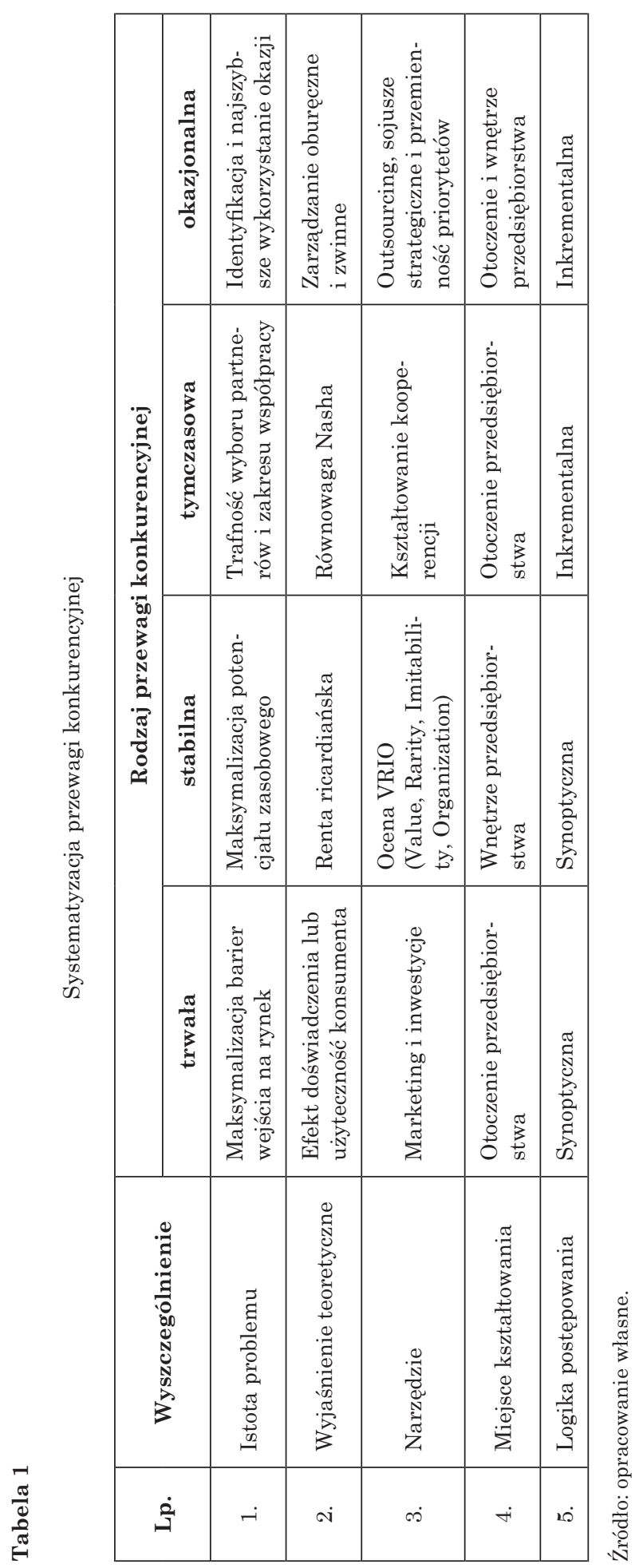


Pozycja lidera funkcjonalności polega na dążeniu do wyróżnienia oferty produktowej. Według Michaela Portera oznacza to, że firma kładzie nacisk na nadanie swym produktom takich cech, na których klientom szczególnie zależy, i następnie tak kształtuje system sprzedaży, aby być jedynym dostawcą zaspokajajacym wymagania odbiorców ${ }^{5}$. Klienci sa gotowi zapłacić wyższa cenę za te unikatowe produkty. Lider funkcjonalności oferuje konsumentom produkty najlepiej trafiajace $\mathrm{w}$ ich gusty i umożliwia im zwiększanie sumy użyteczności, za co konsumenci są skłonni zapłacić więcej. Dostosowanie oferty produktowej do zróżnicowanych gustów konsumentów oznacza jednak rezygnację z masowych rynków i zmusza do operowania w relatywnie małych niszach rynkowych ${ }^{6}$. Warunkiem trwałości osiagniętej przewagi konkurencyjnej jest niezmienność gustów i preferencji konsumentów. Gdy one podlegają przeobrażeniom, walka konkurencyjna zaczyna się od nowa, bariery wejścia do niszy rynkowych przestają bowiem oddziaływać na nowych, pojawiających się konkurentów. Podstawowym problemem strategicznym jest więc dostosowanie oferty produktowej do gustów i preferencji konsumentów oraz zbudowanie barier wejścia do niszy rynkowych, w których przedsiębiorstwo jest obecne.

Innym typem uwarunkowań konkurencyjnych jest możliwość wypracowania stabilnej przewagi konkurencyjnej. W latach osiemdziesiątych Birgel Wernerfelt zauważył, że zwyczajowo dla kształtowania przewagi konkurencyjnej zaleca się zajęcie atrakcyjniejszej pozycji w otoczeniu rynkowym przedsiębiorstwa. Tymczasem, według tego autora, rzeczywistym źródłem tej przewagi jest posiadanie lepszych zasobów ${ }^{7}$. Szczegółowa charakterystyka tej odmiany przewagi konkurencyjnej jest zaprezentowana w kolumnie drugiej tabeli 1.

Kluczowy problem strategiczny dotyczy zatem wyboru właściwych zasobów, w kształtowanie których menedżerowie przedsiębiorstwa powinni się zaangażować. Opanowanie właściwych zasobów pozwala bowiem nieustannie wyprzedzać konkurentów. Przewaga konkurencyjna nie jest stała i wynikająca z opanowania atrakcyjnego udziału rynkowego, wokół którego buduje się bariery wejścia dla innych przedsiębiorstw.

Przedsiębiorstwo posiada zasoby umożliwiające stabilną przewagę konkurencyjna, czyli długookresową zdolność do wyprzedzania konkurentów poprzez innowacyjne oferty produktowe. Zdolność ta wynika z wnętrza firmy, czyli z wyróżniających możliwości kreowanych przez posiadane zasoby ${ }^{8}$. Kształtowanie przewagi konkurencyjnej wymaga permanentnej innowacyjności produktowo-rynkowej, a ta jest możliwa dzięki potencjałowi zasobowemu posiadanemu przez przedsiębiorstwo.

Wyjaśnieniem możliwości utrzymywania stabilnej przewagi konkurencyjnej opartej na posiadanych wyróżniających zasobach może być teoria renty ekonomicznej rozwijana w duchu ricardiańskim. Samo posiadanie zasobów rzadkich pozwala dyskontować rentę różniczkową pierwsza, która umożliwia

${ }^{5}$ M. Porter, op. cit., s. 41.

${ }^{6}$ D. Begg, S. Fischer, R. Dornbuch, Ekonomia, t. 1, PWE, Warszawa 1993, s. 136-160.

7 P. Ghemawat, op. cit., s. 31.

8 M. Sahaf, Strategic Marketing: Making Decision for Strategic Advantage, Prentice Hall, New Delhi 2008, s. 73-76. 
kreowanie wartości większych od marginalnie akceptowanych przez konsumentów. Jeśli te wartości jeszcze zwiększą się z powodu ich szczególnego opanowania w przedsiębiorstwie, to pojawia renta różniczkowa druga. Wreszcie można mówić o rencie różniczkowej trzeciej o lokalizacyjnym charakterze w wypadku opanowania zasobów niemobilnych ${ }^{9}$.

Rzeczywista walka konkurencyjna nie toczy się zatem poza przedsiębiorstwem na rynku, na którym ono działa, lecz we wnętrzu tego przedsiębiorstwa. Celem jest zakumulowanie cenniejszych strategicznie zasobów, one bowiem umożliwiają ustabilizowanie przewagi konkurencyjnej. Stabilna przewaga konkurencyjna wynika z możliwości bycia pierwszym, który oferuje klientom produkty atrakcyjne z ich punktu widzenia. Efektywnościowym skutkiem zasobowego pierwszeństwa są finansowe korzyści wynikające z dyskontowania renty ricardiańskiej. Innymi słowy: pierwszy spija śmietankę, a podążający za nim podlegaja prawu malejących krańcowych przychodów. Przewaga konkurencyjna nie jest wynikiem gry toczonej z konkurentami, lecz jest rezultatem cierpliwej pracy i wysiłku wkładanego w kształtowanie potencjału zasobowego przedsiębiorstwa. Zasoby strategicznie lepsze w kategoriach VRIO ${ }^{10}$ gwarantuja, że przedsiębiorstwo znajduje się przed konkurentami w ofercie rynkowej i dlatego buduje lojalność swoich klientów.

Kolejną odmianą uwarunkowań konkurencyjnych jest możliwość wypracowania tymczasowej przewagi konkurencyjnej. Zachowania przedsiębiorstw na rynku mogą być postrzegane jako rezultat gry, jaka się toczy między nimi o realizację istotnych dla nich wartości. Dążenie wielu przedsiębiorstw do ukształtowania przewagi konkurencyjnej daje się więc interpretować w kategoriach teorii gier. Szczegółowa charakterystyka tej odmiany przewagi konkurencyjnej jest przedstawiona w kolumnie trzeciej tabeli 1.

Podstawowym problemem strategicznym jest zatem wybór partnerów do współpracy w toku działalności gospodarczej oraz zakres działań, w ramach których dopuszczalna jest współpraca z konkurentami. Wykreowana koalicja połączona wspólnotą interesów ekonomicznych ma jednak nietrwały charakter i podlega cyklicznym rekonstrukcjom. Nie jest to gra o sumie zero, współpracujacy konkurenci mają bowiem możliwość wspólnego osiagania sukcesu rynkowego.

Teoria gier jest uznawana za instrumentarium dostarczajace formalnego języka do opisu świadomych i celowych procesów podejmowania decyzji z udziałem jednego lub więcej graczy. Może więc być używana do analizy racjonalnego zachowania w sytuacjach współzależności wyników ${ }^{11}$. Tak właśnie jest w odniesieniu do rywalizacji konkurencyjnej przedsiębiorstw. Jedna z najważniejszych koncepcji wyjaśniających osiągane wyniki jest tzw. równo-

9 B. Czyżewski, The Land Rent Category in Mainstream Economics and its Contemporary Applications, „Journal of Agribusiness and Rural Development” 2008, nr 1 (11), s. 33-34.

${ }^{10}$ W. Miller, Value Maps: Valuation Tools that Unlock Business Wealth, J.Wiley \& Sons, New York 2010, s. 37-38.

${ }_{11}$ M. Ogot, Game Theory in Strategic Management, http://erepository.uonbi.ac.ke:8080/ bitstream/handle/123456789/9848/aibuma2011_submission_25\%20-\%20Game\%20Theory\%20 in\%20Strategic\%20Management.pdf?sequence=1, s. 2 (dostęp: 3.03.2013). 
waga Nasha. Zakłada ona, że uczestnicy gry podejmują decyzje, kierując się nie tylko obiektywnymi przesłankami, jak w normalnym procesie decyzyjnym, lecz także biora pod uwagę również decyzje innych uczestników gry. Według Nasha każda gra o skończonej liczbie strategii realizowanych przez poszczególnych graczy ma przynajmniej jeden stan równowagi, czyli sytuację, w której żadnemu graczowi nie opłaca się zmienić realizowaną strategię. Ale każda taka gra może posiadać więcej stanów równowagi ${ }^{12}$.

Jednak gdyby wszyscy gracze zadowalali się osiagniętą równowagą Nasha, to ich wygrane miałyby stały charakter. Jednak tak nie jest, zmieniają się bowiem warunki, w których gra jest prowadzona (zmiany popytu i zmiany podaży), oraz pojawiają się nowi gracze, a nawet dotychczasowi gracze są skłonni dążyć do innej równowagi Nasha. Ukształtowany stan równowagi jest zatem tylko tymczasowy. Przedsiębiorstwo osiaga zadowalająca je pozycję konkurencyjna tylko na krótki czas, po czym wskutek zmiany uwarunkowań zaczyna realizować wyniki ekonomiczne (wygrane w grze) poniżej akceptowanych przez interesariuszy. Jest więc zmuszone do poszukiwania nowej strategii i nowej pozycji konkurencyjnej. W toku tych poszukiwań kreuje koalicjantów, z którymi łączy je wspólny interes ekonomiczny. Przedsiębiorstwa zaczynaja zatem jednocześnie konkurować i współpracować ze sobac. Pojawia się zjawisko nazywane kooperencją (kopetycja) ${ }^{13}$. Jest ono tym częstsze, im szybciej zmieniają się warunki prowadzonej gry.

Wreszcie można mówić o uwarunkowaniach konkurowania uniemożliwiajacych wypracowanie jakiejkolwiek intencjonalnej przewagi konkurencyjnej. Może ona mieć tylko okazjonalny charakter, czyli jest okazjonalna przewaga konkurencyjna. Szczegółowa charakterystyka tej odmiany przewagi konkurencyjnej jest przedstawiona w kolumnie czwartej tabeli 1.

Lucy Thomas i Richard D'Aveni ${ }^{14}$ uważaja, że przyczyną tego stanu jest wszechobecny dynamizm innowacyjny realizowany wzdłuż całego łańcucha dostaw, od jego początku aż do klienta finalnego, na dodatek przez cały czas istnienia tego łańcucha. Ukształtowana pozycja konkurencyjna nie jest wobec tego w żadnym momencie trwała, przeciwnie - jej źródła podlegają nieustannej erozji. Zdobycie przewagi konkurencyjnej rzadko jest wynikiem posiadania jakichś szczególnych zasobów, co najwyżej mogły one być powodem sukcesu w przeszłości, a z punktu widzenia nieznanej przyszłości są zwykle blokada rozwoju przedsiębiorstwa. Dostosowanie do nowej sytuacji konkurencyjnej najczęściej wymaga destrukcji posiadanych zasobów, czyli przypomina istotę konkurowania w sensie schumpeterowskim. Wymaga wydostania się z „klatki zasobowej" przez jej rozmontowanie. Utrzymywanie zdolności do strategicznego manewrowania zasobami wprowadza do przedsiębiorstwa nieustanną płynność, czyli chaos.

${ }_{12}$ T. Włudyka, M. Smuga (red.), Instytucje gospodarki rynkowej, Wolters Kluwer Polska, Warszawa 2012, s. 71.

${ }_{13}$ J. Cygler, Kooperencja - nowy typ relacji między konkurentami, „Organizacja i Kierowanie” 2007, nr 2 (128), s. 61.

${ }^{14}$ L. Thomas, R. D'Aveni, The Rise of Hipercompetition from 1950 to 2002: Evidence of Increasing Structural Destabilization and Temporary Competitive Advantage, http://www2.sa.unibo.it/ seminari/Papers_Bajo-Corrado/daveni.pdf, s. 9-11 (dostęp: 3.03.2012). 
Konkurowanie odbywa się „na krawędzi chaosu”, a przewagę konkurencyjną zdobywa się dzięki „skokowi na dużą falę”, na której surfuje się ku sukcesowi. Kluczowym problemem strategicznym staje się więc zidentyfikowanie i wykorzystanie nadchodzącej okazji, która szybko zostanie wykorzystana przez konkurentów i może być dla przedsiębiorstwa szansa, jeśli zostanie dostrzeżona i wykorzystana, albo zagrożeniem, jeśli wykorzystaja ją konkurenci ${ }^{15}$.

Kształtowanie przewagi konkurencyjnej wymaga zatem napiętej uwagi i uruchamiania nieustannych manewrów strategicznych, dzięki którym przedsiębiorstwo staje się zwinniejsze od swoich konkurentów. Zwinne przedsiębiorstwa są bliższe rynkom, na których działaja, i potrafią szybciej dostosowywać się do ewoluujących wymagań i oczekiwań klientów. Jest to możliwe dzięki strategicznemu przywództwu wewnątrz przedsiębiorstwa, powszechnemu wykorzystaniu technologii informacyjno-komunikacyjnych oraz elastycznej współpracy z dostawcami ${ }^{16}$.

Powyższe charakterystyki poszczególnych typów przewagi konkurencyjnej można traktować jako wypracowane w nauce o zarządzaniu koncepcje teoretyczne. Teoria zawsze może być konfrontowana z realiami. W następnej części opracowania zostaną opisane przypadki dwóch wybranych przedsiębiorstw, które w różnym czasie w różny sposób budowały swe powodzenie ekonomiczne.

\section{EGZEMPLIFIKACJE ZACHOWAŃ PRZEDSIĘBIORSTW}

Jednym z najbardziej znanych współcześnie przedsiębiorstw jest niewątpliwie Nokia Corporation. Powstała ona w 1967 r. w wyniku połączenia firmy Nokia - dawnej fabryki papieru - z Fińskimi Zakładami Gumowymi i Fińską Fabryką Kabli ${ }^{17}$. W szczególności to ostatnie przedsiębiorstwo znacząco zaważyło na przyszłości Nokii. Fińska Fabryka Kabli zbliżyła bowiem korporację do obszaru technologii informacyjno-telekomunikacyjnych. Tam właśnie podjęto pierwsze próby uruchamiania działalności w sektorze elektroniki. Zwraca uwagę, że wysiłki te przez długi czas (aż do początku lat osiemdziesiątych XX w.) pozostawały na marginesie zasadniczej działalności korporacji. Powoli jednak budowano bazowa wiedzę w dziedzinie radiotelefonii i technologii łączności. Osiagnięcia te stopniowo orientowały korporację jako całość na obszar technologii informacyjno-telekomunikacyjnych. Od lat osiemdziesiątych właśnie $\mathrm{w}$ ten zakres skierowano kluczowe inwestycje, a rozwój korporacji jako całości skoncentrowano na tych technologiach. Internacjonalizacja Nokii, a przede wszystkim kumulacja kompetencji w dziedzinie telekomunikacji odbywały się dzięki przejmowaniu innych przedsiębiorstw. Za szczególnie istotne uważa się nabycie w 1981 r. fińskiej firmy Televa z jej doświadczeniem

${ }^{15}$ C. Bingham, K. Eisenhardt, N. Furr, Which Strategy When?, „MIT Sloan Management Review" 2011, Fall, s. 76.

${ }^{16}$ S. Trzcieliński, Przedsiębiorstwo zwinne, Wyd. PP, Poznań 2011, passim.

${ }^{17}$ Nokia, 2011, http://pl.wikipedia.org/wiki/Nokia (dostęp: 27.02.2011). 
w dziedzinie stacji bazowych i łączności oraz początkowo założenie spółki joint venture z fińską firmą Salora i jej przejęcie w 1984 r., co ukierunkowało Nokię na produkcję telefonów komórkowych. Nie obyło się jednak bez porażek. Tak można ocenić wysiłki Nokii z lat osiemdziesiątych mające na celu rozwój produkcji odbiorników telewizyjnych i komputerów. Przełom lat osiemdziesiątych i dziewięćdziesiątych XX w. okazał się dla Nokii okresem bardzo trudnym, co wynikało z kryzysu ekonomicznego, jaki dotknął wówczas Finlandię związaną bardzo mocno gospodarczo z przeżywającym zapaść Związkiem Radzieckim. Zbycie ekonomicznie nietrafionych spółek zależnych oraz wykorzystanie możliwości wprowadzenia europejskiego standardu w dziedzinie telefonicznej łączności cyfrowej otworzyło przed korporacją nowe perspektywy ${ }^{18}$.

Jaakko Aspara i inni, analizujac ewolucję modelu biznesu Nokii, identyfikują w ostatnim ćwierćwieczu trzy kolejne jego postacie:

- model korporacji jako całości (okres sprzed końca lat osiemdziesiątych),

- model sektora mobilnej telefonii (przełom lat osiemdziesiątych i dziewięćdziesiątych),

- model odnowionej korporacji jako całości (po 1997 r.) ${ }^{19}$.

W latach dziewięćdziesiątych można było sądzić, że Nokia wypracowała trwała lub stabilną przewagę konkurencyjna. Efekt skali powodował, że produkcja telefonów komórkowych była relatywnie tania, wysoka jakość zapewniała bardzo dobre opinie klientów, polityka dywidend była magnesem dla giełd papierów wartościowych i wysokiej jakości zasoby ludzkie umożliwiały stały dynamizm innowacyjny. Bariery wejścia na rynki opanowane przez Nokię wydawały się nie do pokonania przez konkurentów.

Jednak już w XXI w. zaczęły się kłopoty. Nokia odnotowała spadek udziału w rynku światowym telefonów komórkowych z około 35,8\% w 2002 r. do $30 \% \mathrm{w}$ ciagu pierwszych trzech miesięcy 2005 r. Na europejskim rynku spadek wyniósł z 51\% w 2002 r. do 32,6\% w 2004 r. Notowania akcji Nokii spadły o $14 \%{ }^{20}$. Nokia nie dostrzegła na czas skutków postępu technologicznego, który pozwolił ominąć bariery wejścia na rynki telefonów komórkowych takim firmom, jak przede wszystkim Apple czy Samsung. A właściwie nie na rynek telefonów komórkowych, lecz smartphone'ów, czyli mobilnych i miniaturowych komputerów.

Przykład sukcesu firmy Apple związany jest z projektem iPod. Apple był przedsiębiorstwem postrzeganym jako producent zaawansowanego sprzętu elektronicznego. W ten obraz wpisywał się z pewnościa produkt pod nazwą iPod. Ponieważ pozwalał on na mobilne użytkowanie i przechowywanie w chmurze utworów muzycznych, słuchowisk, filmów i fotografii, łatwo można było wpaść na pomysł, aby użytkownik mógł dzielić się tymi zbiorami i pozyskiwać je z zewnątrz. Umożliwiała to funkcjonalność iPoda pozwalająca łączyć się z internetem za pośrednictwem komputera. Apple przekształcił swój

${ }_{18}$ J. Aspara et al., Stratetgic Management of Business Model Transformation: Lessons from Nokia, „Management Decision” 49, 2011, nr 4, s. 15-16.

${ }_{19}$ Ibidem, s. 17.

${ }^{20}$ J. McCray, J. Gonzalez, Crisis Management in Smart Phones: The Case of Nokia versus Apple, „European Business Review” 23, 2011, nr 3, s. 243. 
Tabela 2

Ewolucja modelu biznesowego Nokia Corporation

\begin{tabular}{|c|c|c|c|}
\hline Wyszczególnienie & $\begin{array}{l}\text { Model korporacji } \\
\text { jako całości }\end{array}$ & $\begin{array}{c}\text { Model sektora } \\
\text { mobilnej telefonii }\end{array}$ & $\begin{array}{c}\text { Model odnowionej } \\
\text { korporacji jako } \\
\text { całości }\end{array}$ \\
\hline \multicolumn{4}{|c|}{ Strategia i struktura } \\
\hline Dziedzina & Mobilne telefony & $\begin{array}{l}\text { Zróżnicowany wachlarz } \\
\text { działalności biznesowych }\end{array}$ & $\begin{array}{l}\text { Mobilne telefony i tele- } \\
\text { komunikacja }\end{array}$ \\
\hline Działania & $\begin{array}{l}\text { Współpraca zmierzająca } \\
\text { do stanowienia } \\
\text { standardów }\end{array}$ & Fuzje i przejęcia & $\begin{array}{l}\text { Wewnętrzny rozwój pro- } \\
\text { duktów i joint venture }\end{array}$ \\
\hline Rozwój & Wzrost organiczny & $\begin{array}{l}\text { Szybka internacjona- } \\
\text { lizacja }\end{array}$ & Wzrost organiczny \\
\hline $\begin{array}{l}\text { Przesłanki } \\
\text { wyróżnienia }\end{array}$ & $\begin{array}{l}\text { Doskonałość produk- } \\
\text { cyjna, wiedza techno- } \\
\text { logiczna, orientacja na } \\
\text { klienta }\end{array}$ & $\begin{array}{l}\text { Orientacja na zaawan- } \\
\text { sowana technologię } \\
\text { i komercjalizacja tech- } \\
\text { nologii własnej i obcej }\end{array}$ & $\begin{array}{l}\text { Orientacja na klienta } \\
\text { i integracja technologii }\end{array}$ \\
\hline Logika ekonomiczna & $\begin{array}{l}\text { Szybki wzrost przez roz- } \\
\text { szerzanie asortymentu } \\
\text { produktów }\end{array}$ & $\begin{array}{l}\text { Stabilny wzrost przez } \\
\text { optymalizacje portfela } \\
\text { strategicznego (BCG) }\end{array}$ & $\begin{array}{l}\text { Zrównoważone portfolio } \\
\text { produktów i doskona- } \\
\text { łość operacyjna }\end{array}$ \\
\hline \multicolumn{4}{|c|}{ Sieć biznesowa } \\
\hline $\begin{array}{l}\text { Relacje } \\
\text { z interesariuszami }\end{array}$ & $\begin{array}{l}\text { Bezpośrednia orientacja } \\
\text { na klienta i relatywna } \\
\text { wolność od nadzoru } \\
\text { właścicielskiego }\end{array}$ & $\begin{array}{l}\text { Kompleksowe i wielopo- } \\
\text { ziomowe uzależnienie } \\
\text { od politycznych, spo- } \\
\text { łecznych i rządowych } \\
\text { interesariuszy }\end{array}$ & $\begin{array}{l}\text { Bezpośrednia orientacja } \\
\text { na klienta oraz koncen- } \\
\text { tracja uwagi na właści- } \\
\text { cieli i władze }\end{array}$ \\
\hline \multicolumn{4}{|c|}{ Operacje } \\
\hline $\begin{array}{l}\text { Architektura } \\
\text { procesowa }\end{array}$ & $\begin{array}{l}\text { Architektura hierar- } \\
\text { chiczna z początkami } \\
\text { orientacji na procesy } \\
\text { poziome }\end{array}$ & $\begin{array}{l}\text { Procesy ukierunkowane } \\
\text { głównie na wymagania } \\
\text { zarządzania ze szczegól- } \\
\text { nym uwzględnieniem } \\
\text { decyzji inwestycyjnych } \\
\text { oraz działań dotyczą- } \\
\text { cych fuzji i przejęć }\end{array}$ & $\begin{array}{l}\text { Architektura nakie- } \\
\text { rowana na spójność } \\
\text { i efektywność procesów } \\
\text { poziomych }\end{array}$ \\
\hline $\begin{array}{l}\text { Potencjał zasobowy } \\
\text { i kompetencyjny }\end{array}$ & $\begin{array}{l}\text { Silna koncentracja na } \\
\text { niejawnych aktywach } \\
\text { i na umiejętnościach } \\
\text { pracowników }\end{array}$ & $\begin{array}{l}\text { Duże zróżnicowanie } \\
\text { cech i poziomu zasobów } \\
\text { i kompetencji w różnych } \\
\text { jednostkach bizneso- } \\
\text { wych }\end{array}$ & $\begin{array}{l}\text { Silna koncentracja na } \\
\text { niejawnych zasobach } \\
\text { w dziedzinie wiedzy, } \\
\text { umiejętności pracowni- } \\
\text { ków i patentów }\end{array}$ \\
\hline $\begin{array}{l}\text { Oferowane } \\
\text { produkty i usługi }\end{array}$ & $\begin{array}{l}\text { Skoncentrowane na } \\
\text { jednym biznesie }\end{array}$ & $\begin{array}{l}\text { Zróżnicowane w róż- } \\
\text { nych biznesach }\end{array}$ & $\begin{array}{l}\text { Skoncentrowane na } \\
\text { jednym biznesie }\end{array}$ \\
\hline \multicolumn{4}{|c|}{$\begin{array}{l}\text { Finanse i rachunkowość } \\
\end{array}$} \\
\hline $\begin{array}{l}\text { Budżetowanie } \\
\text { kapitałowe }\end{array}$ & $\begin{array}{l}\text { Podporządkowanie } \\
\text { budżetowi korporacji }\end{array}$ & $\begin{array}{l}\text { Standardowe budżeto- } \\
\text { wanie z dużą wyrozu- } \\
\text { miałością właścicieli }\end{array}$ & $\begin{array}{l}\text { Budżetowanie ściśle } \\
\text { kontrolowane przez } \\
\text { właścicieli }\end{array}$ \\
\hline $\begin{array}{l}\text { Raportowanie } \\
\text { finansowe }\end{array}$ & $\begin{array}{l}\text { System rachunkowo- } \\
\text { ści zestandaryzowany } \\
\text { w korporacji }\end{array}$ & $\begin{array}{l}\text { Kompleksowa sprawo- } \\
\text { zdawczość finansowa } \\
\text { dostosowana do zróżni- } \\
\text { cowania biznesów }\end{array}$ & $\begin{array}{l}\text { Rozwinięta sprawo- } \\
\text { zdawczość dostosowana } \\
\text { do wymagań właścicieli }\end{array}$ \\
\hline
\end{tabular}

Źródło: J. Aspara et al., op. cit., s. 17-18. 
model biznesu z innowacyjnego producenta na integratora i brokera internetowego ${ }^{21}$. Z czasem Apple rozwinął swą ofertę, promując także iPhone'a i iPada. Kluczem do sukcesu Apple okazało się sprzęgnięcie inteligentnego telefonu z internetem oraz opracowanie ok. 1000 aplikacji umożliwiających każdemu dowolne kształtowanie własnego sposobu komunikowania się ze światem i budowanie własnych baz danych. Apple dostosował się do oczekiwań klientów i potrafił zbudować model biznesu wyzwalający aktywność użytkowników posiadaczy urządzeń Apple’a.

Apple doskonale zidentyfikował okazje kreowane przez nowe technologie informacyjno-telekomunikacyjne oraz potrafił je wykorzystać, wdrażając niezwykle efektywny system zarządzania projektami związanym z ponad 1000 projektów różnych aplikacji. Dodatkowo wykreował możliwość indywidualnego kształtowania przez każdego klienta prywatnych baz danych oraz własnych społeczności internetowych. Nokia trwała przy dawnym modelu biznesu, dlatego coraz bardziej oddalała się od zmienionych źródeł konkurencyjności. Apple okazał się natomiast przedsiębiorstwem zwinnym.

Powodzenie ekonomiczne $\mathrm{w}$ płynnych czasach zapewniło zatem firmie Apple wdrożenie idei zwinnego przedsiębiorstwa. W kolejnym fragmencie dokonano rekonstrukcji i interpretacji tejże koncepcji.

\section{KONCEPCJA ZWINNEGO PRZEDSIĘBIORSTWA}

Zwinne przedsiębiorstwo wspiera się na kilku kluczowych filarach, mianowicie: jest blisko rynku i klienta finalnego, cechuje się strategicznym przywództwem, posiada elastyczny potencjał operacyjny, sprawnie współpracuje z dostawcami oraz wykorzystuje informatyczne systemy wspierające zarządzanie. Rynkowo, albo wręcz na jednostkowego klienta finalnego, zorientowane przedsiębiorstwa powinny jednak robić to w nowoczesnej formie. Można bowiem wyróżnić dwie odmiany tej orientacji - związana z rozwojem produktu oraz włączająca klienta w proces strategiczny przedsiębiorstwa ${ }^{22}$. Bliskość rynku i klienta oparta na rozwoju produktu polega na stałym prowadzeniu badania satysfakcji klientów i na tej podstawie projektowaniu produktu, a następnie dostarczaniu go w niezawodny i bezpieczny sposób odbiorcy finalnemu oraz zapewnieniu mu przyjaznej i szybko reagującej obsługi posprzedażnej ${ }^{23}$. Można uznać, że jest to tradycyjny sposób realizacji aktywnego marketingu. Zwinne przedsiębiorstwo wymaga bardziej wysublimowanej aktywności marketingowej, właśnie przez włączenie (inkluzję) klienta finalnego w kształtowanie strategii przedsiębiorstwa. Używając terminologii Alvina Tofflera - chodzi

${ }^{21}$ H. Fraser, Design Business: New Model for Success, „Design Management Review” 2009, June, s. 62-63.

${ }^{22}$ H. Liao, M. Subramony, Employee Customer Orientation in Manufacturing Organizations: Join Influences of Customer Proximity and the Senior Leadership Teams, „Journal of Applied Psychology" 93, 2008, nr 2, s. 317.

23 Ibidem. 
o rezygnację $\mathrm{z}$ traktowania klienta jako konsumenta, a dostrzeżenie $\mathrm{w}$ nim prosumenta $^{24}$. Kluczowym czynnikiem włączajacym klienta w formowanie strategii przedsiębiorstwa jest zbudowanie metryk lojalnościowych i utrzymywanie aktywnej komunikacji z klientami najczęściej za pomocą social media. Na podstawie swoich doświadczeń eksperci z firmy Ipsos Loyality ${ }^{25}$ wskazują zawodność tradycyjnego sposobu mierzenia lojalności klientów za pomoca tzw. SOW (Share of Wallet), czyli procentowego udziału wydatków klienta na produkt, który firma sprzedaje, w relacji do ogółu zakupów na rynku tej grupy produktów w danym okresie ${ }^{26}$. Zawodność ta wynika z faktu, że zmiany satysfakcji klienta koreluja ze zmianami SOW na poziomie zaledwie 0,1 , natomiast proponowany przez nich wskaźnik WARs (Wallet Allocation Rule score), który bierze pod uwagę zarówno miarę preferencji marki, jak i liczbę marek obecnych na rynku jest skorelowany ze stopniem satysfakcji klienta na poziomie $0,9^{27}$. Miernik ten w swym polu recepcji zawiera aktywność klienta (jako prosumenta) i ona właśnie staje się współcześnie najważniejszym wskaźnikiem konkurencyjności oferty produktowej.

W zwinnym przedsiębiorstwie na plan pierwszy wysuwają się procesy zarządzania doświadczeniem klienta (Customer Experience Management CEM), czyli system śledzenia, nadzorowania i organizowania wszelkich interakcji między przedsiębiorstwem a klientem ${ }^{28}$. Wykorzystywany w toku CEM tzw. social CRM jest - wg Paula Greenberga - filozofią i strategia biznesowa wykorzystująca technologię informacyjno-komunikacyjną w celu wciagnięcia klienta w dyskusję pozwalająca kreować dwustronne korzyści ${ }^{29}$. CEM jest działalnością wykorzystująca takie na przykład platformy społecznościowe, jak Facebook, Google+, LinkedIn, czy Twitter. CEM to jednak coś innego niż CRM, różnice dotyczą tego, że:

a) CEM pozwala ustalić, co klient myśli o firmie, natomiast CRM pozwala poznać, co klient wie o firmie,

b) CEM realizuje się w czasie rzeczywistym, natomiast CRM umożliwia analizę ex post,

c) CEM opiera się na ukierunkowanych badaniach obserwacyjnych, natomiast CRM na badaniach rynku i śledzeniu sprzedaży,

${ }_{24}$ Prosument (ang. prosumer - professional/producer + consumer) - kalka językowa i kontaminacja słów - profesjonalista/producent i konsument - konsument zaangażowany w współtworzenie i promowanie produktów ulubionej marki czy jednoczesną produkcję oraz konsumpcję dóbr i usług; http://pl.wikipedia.org/wiki/Prosument (dostęp: 2.04.2013).

25 „Trzecia pod względem wielkości na świecie grupa badawcza dostarczająca danych na podstawie wywiadów - korzysta z szerokiego wachlarza metod: od wywiadów i analiz jakościowych do najbardziej innowacyjnych technik zbierania i przetwarzania danych ilościowych"; http://www. ipsos.pl/grupa (dostęp: 2.04.2013).

${ }_{26}$ Zob. http://dobrebadania.pl/slownik-badawczy.html?b=baza\&szczegolowo=1150 (dostęp: 2.04.2013).

27 T. Keiningham et al., Customer Loyalty Isn't Enough. Grow Your Share of Wallet, „Harvard Business Review" 2011, October, s. 143.

${ }^{28} \mathrm{Zob}$. http://searchcrm.techtarget.com/definition/customer-experience-management (dostęp: 2.04.2013).

${ }_{29}$ Zob. http://the56group.typepad.com/pgreenblog/2009/07/time-to-put-a-stake-in-the-ground-on-social-crm.html (dostęp: 2.04.2013). 
d) CEM ma wiodacy charakter, identyfikuje bowiem lukę między oczekiwaniami a doświadczeniem, natomiast CRM wspiera sprzedaż krzyżowa, ponieważ pozwala kompletować ofertę dla klienta ${ }^{30}$.

Wyniki badań opublikowane przez Boston Consulting Group pokazuja, że 89\% respondentów wywodzących się z kierownictwa komórek marketingowych podejmuje decyzje, uwzględniając przesłanki zbierane poprzez social media, a $82 \%$ spośród nich jest zdania, że social media mają poważny wpływ na świadomość marki oferty produktowej ich przedsiębiorstw. Ponadto spośród ponad 3 tys. reprezentantów wyższego kierownictwa pionów marketingowych firm z czołowej setki najpopularniejszych rankingów biznesowych w USA aż 77\% wskazało w 2012 r., że obserwacja social media jest ważną funkcją marketingowa, a odsetek ten wzrósł o 6 punktów procentowych w ciagu $2010 \mathrm{r}$. i o 4 punkty w ciagu $2011 \mathrm{r}^{31}$

CEM pozwala zatem budować nie tyle wartość dla klienta, ile wartość z klientem, który staje się „współwytwórcą wartości”32. Menedżer przestaje zatem być dysponentem zasobów wewnątrz firmy, powinien dodatkowo aktywnie współoddziaływać z klientami. Zarządzanie przedsiębiorstwem rozumiane klasycznie zostaje zastapione przez przywództwo strategiczne.

Przywództwo strategiczne jest niezbędnym składnikiem pracy menedżerów, która ewoluuje w kierunku określanym przez Gary'ego Hamela jako odchodzenie od roli „wszechwiedzacych decydentów” ku roli „społecznych architektów”, dążących do uwolnienia najlepszego myślenia i pełnego potencjału zatrudnionych $\mathrm{w}$ przedsiębiorstwie w kontekście budowania satysfakcji zewnętrznych odbiorców oferty produktowej ${ }^{33}$. Strategiczne przywództwo jest określane jako praca menedżerska polegająca na prowadzeniu przedsiębiorstwa i przede wszystkim skupiająca się na kreowaniu i wdrażaniu zmian strategicznych dotyczących przedsiębiorstwa jako całości ${ }^{34}$. Według Kets de Vriesa wymaga to odgrywania dwojakiej roli. Po pierwsze, charyzmatycznego przywódcy i po drugie, kreatora strategicznej architektury organizacyjnej. Szczególnie ważna jest ta pierwsza rola, to dzięki niej bowiem tworzona jest wizja działalności, dokonuje się upełnomocnienie (empowerment) zatrudnionych i wyzwalany jest $\mathrm{u}$ nich imagineering ${ }^{35}$. W warunkach nietrwałej, a więc tymczasowej albo okazjonalnej przewagi konkurencyjnej zadaniem menedżerów staje się „kreowanie i zdominowanie pojawiających się szans i możliwości”36.

${ }^{30}$ C. Meyer, A. Schwanger, Understanding Customer Experience, „Harvard Business Review” 2007, February, s. 4.

31 R. Berkman, CMOs Using Social Data to Flex Their Muscle, „MIT Sloan Management Review”, 8 April 2013, http://sloanreview.mit.edu/article/cmos-using-social-data-to-flex-their-muscle/?utm_ source=facebook\&utm_medium=social\&utm_campaign=sm-direct (dostęp: 9.04.2013).

${ }^{32}$ K. Rogoziński, Zarzqdzanie wartościq z klientem, Wolters Kluwer Polska, Warszawa 2012, s. $321-336$.

${ }^{33}$ A. Gast, M. Zanini, The Social Side of Strategy, „McKinsey Quarterly” 2012, May https:// www.mckinseyquarterly.com/The_social_side_of_strategy_2965\#footnote7up (dostęp: 7.04.2013).

${ }_{34}$ J. Thompson, Strategic Management: Awareness and Change, Thomson, London 2003, s. 413 .

${ }^{35}$ Imagineering jest kontaminacją słów imaginacja (wyobraźnia, fantazja) i inżyniera. Ibidem, s. 414.

${ }^{36}$ G. Hamel, C. Prahalad, Przewaga konkurencyjna jutra. Strategie przejmowania kontroli nad branża i tworzenia rynków przyszłości, Business Press, Warszawa 1999, s. 19. 
Gary Hamel i Coimbatore Prahalad podkreślają bardzo stanowczo, że dążenie do jak największego udziału w rynku to za mało, należy jeszcze dążyć do jak największego udziału w otwierających się możliwościach. Reaktywne zachowania menedżerskie nie wystarczaja, konieczne sa zachowania proaktywne. Te ostatnie są skuteczne, gdy dąża do nich całe zespoły zatrudnionych w przedsiębiorstwie. Łączyć je powinna wspólna wizja biznesu, którą wytycza właśnie przywódca. Przywódca strategiczny powinien rozwiązywać problemy o charakterze:

a) organizacyjnym: właściwa struktura, zbiorowe kompetencje i upełnomocnienie jednostek,

b) technologicznym: orientacja na produkt, proces biznesowy i technologię oraz imperatyw ich integracji,

c) humanistycznym: orientacja na zespołowość, kompetencje i kulturę ${ }^{37}$.

W rezultacie możliwe staje się połączenie działań polegających na projektowaniu (design) produktu, projektowaniu (design) systemu wytwarzania i zarządzaniu innowacjami. Końcowym efektem jest oferowanie na rynku spersonalizowanego produktu o najwyższej jakości po najniższej cenie ${ }^{38}$. Jest to szczególnie ważne w sytuacji tzw. utowarowienia. Proces ten pojawia się, gdy konieczne jest podnoszenie jakości albo innych wartości użytkowych produktu w warunkach stałej obniżki jego ceny na rynku. Stała tendencja spadku cen jest konsekwencją bardzo szybkiego naśladownictwa ze strony wszystkich konkurentów ${ }^{39}$.

Przykładem zastosowania designingu może być kształtowanie produktu przez firmę Nike. Rzecz dotyczy oferty w dziedzinie sportowego obuwia do biegania. Z jednej strony, co oczywiste, buty winny być zaprojektowane w zgodzie z wymaganiami fizjologicznymi i anatomicznymi użytkowników. Oznacza to zwykłe podejście marketingowe zorientowane na wymagania klienta finalnego. Zrozumiałe jest także dążenie do wykonania tych butów z materiałów przyjaznych środowisku naturalnemu. Osoby biegajace same sa zapewne przykładem zdrowego stylu życia, zatem uprawnione jest przypuszczenie, że podzielaja przekonania o potrzebie ochrony naturalnego środowiska. Projekt ekologicznego obuwia odpowiada jednak na wymagania szerszego kręgu interesariuszy i wpisuje się w idee społecznej odpowiedzialności biznesu. Osoby biegające reprezentuja jednak zazwyczaj specjalne osobowości, nastawione na czerpanie radości z życia i są z reguły istotami towarzyskimi. Bieganie poniekąd izoluje je od społeczności, do której należą. Firma Nike zdecydowała się montować w obuwiu specjalne urządzenia elektroniczne umożliwiające bezprzewodowa łączność z iPhone'em i przez to dajace szansę na stała komunikację z innymi. Taki model obuwia został wprowadzony na rynek w 2006 r. i trzy lata później w USA firma sprzedała już 1,3 mln par tych butów ${ }^{40}$. Podejście

${ }^{37}$ F. B. Vernadat, Research Agenda for Agile Manufacturing, „International Journal of Agile Management Systems" 1, 1999, nr 1, s. 38.

38 Ibidem.

39 R. D'Aveni, Beating the Commodity Trap, Harvard Business Press, Boston 2010, s. 4.

${ }^{40}$ H. Fraser, Design Business: New Model for Success, „Design Management Review” 2009, June, s. 59. 
to wykorzystuje możliwości otwierane przez postęp naukowo-techniczny i pozwala wciagnaćc klientów w proces tworzenia wyrobu finalnego. Konkurenci maja jednak także dostęp do tych osiagnięć i doświadczeń, zatem relatywnie szybko zaoferuja produkty podobne, a może i udoskonalone. Wykorzystanie okazji nie jest więc długotrwałe. Po krótkim czasie przywódca strategiczny powinien uruchomić lub wesprzeć nowe pomysły.

Z operacyjnego punktu widzenia wymaga to bardzo elastycznego potencjału produkcyjnego, łatwo przezbrajanego z jednej działalności na inną. Elastyczność systemów produkcyjnych może być opisana i zmierzona w kilku wymiarach:

a) zakres, czyli liczba opcji, jakie system albo zasoby mogą osiagnąć,

b) heterogeniczność, czyli stopień zróżnicowania każdej z opcji,

c) mobilność, czyli łatwość przechodzenia z jednego stanu do innego stanu,

d) uniformizacja, czyli stopień poprawy albo pogorszenia systemu w rezultacie dokonanej zmiany ${ }^{41}$.

Oczywiście elastyczność jest tym lepsza, im system produkcyjny ma więcej opcji, które są mocno wzajemnie zróżnicowane, łatwo jest przejść z jednego stanu do drugiego i odbywa się to niewielkim kosztem. Silnie zróżnicowany system łatwo i tanio się zmieniający jest dobrze dostosowany do zmiennego i nawet nieprzewidywalnego otoczenia. Atrybut elastyczności jest więc wielowymiarowy. Przyczyny i opis tej różnorodności prezentuje tabela 3.

Tabela 3

Odmiany elastyczności

\begin{tabular}{|l|l|}
\hline \multicolumn{1}{|c|}{ Obiekt } & \multicolumn{1}{c|}{ Definicja } \\
\hline Maszyna & $\begin{array}{l}\text { Łatwość wprowadzania niezbędnych zmian w celu wytworzenia danego } \\
\text { zestawu typów części }\end{array}$ \\
\hline Proces & $\begin{array}{l}\text { Zdolność do wytwarzania danego zestawu rodzajów części, z których każda } \\
\text { może powstać z wykorzystaniem różnych materiałów, na kilka sposobów }\end{array}$ \\
\hline Produkt & $\begin{array}{l}\text { Możliwość przejścia do produkcji nowego (zestawu) produktu(ów) bardzo } \\
\text { szybko i ekonomicznie }\end{array}$ \\
\hline Trasowanie & Zdolność do obsługi awarii, żeby produkować określony zestaw typów części \\
\hline Wielkość & $\begin{array}{l}\text { Zdolność do generowania zyskownych zleceń produkcyjnych niezależnie od } \\
\text { wielkości produkcji }\end{array}$ \\
\hline Ekspansja & $\begin{array}{l}\text { Zdolność budowania systemu i rozszerzania go w razie potrzeby, łatwo } \\
\text { i modułowo }\end{array}$ \\
\hline Operacja & Możliwość zamiany kolejności kilku operacji \\
\hline Produkcja & Uniwersalny zestaw możliwości produkcyjnych \\
\hline
\end{tabular}

Źródło: R. Beach et al., A Review of Manufacturing Flexibility, „European Journal of Operational Research" 122, 2000, nr 1, s. 46.

${ }^{41}$ L. Koste, M. Malhotra, S. Sharma, Measuring Dimensions of Manufacturing Flexibility, „Journal of Operations Management” 22, 2004, nr 2, s. 172. 
Osiagnięta elastyczność działalności przedsiębiorstwa przenosi się na wymagania wobec dostawców. Pożądane stają się tzw. zwinne kanały dostaw. Właściwe zarządzanie kanałami dostaw powinno umożliwiać kooperującym przedsiębiorstwom takie projektowanie produktów, ich wytwarzanie i dostarczanie odbiorcom finalnym, aby maksymalizować wzajemne korzyści. Zarzadzanie to powinno być podporządkowane czterem głównym celom: budowie przewagi konkurencyjnej, ułatwianiu indywidualizacji obsługi klienta opartej na możliwie długich seriach produkcyjnych, minimalizacji poczucia niepewności i ułatwianiu wdrażania zmian oraz kreowaniu innowacyjności pracowników w każdym z ogniw łańcucha dostaw ${ }^{42}$. Zwinny łańcuch dostaw powinien się składać z ogniw, którymi są zwinne przedsiębiorstwa. Nie jest to możliwe bez wyjątkowo precyzyjnej koordynacji i synchronizacji ich działań. W sukurs kierownictwom tych firm niewątpliwie idzie obecnie technologia informacyjno-telekomunikacyjna.

Jak to wyżej wskazano, we współczesnej gospodarce charakteryzującej się hiperkonkurencyjnościa, wyróżnianie się jakościa produktu nie jest już istotnym źródłem przewagi konkurencyjnej. Dążenie do taniej oferty produktowej dostosowanej do zindywidualizowanych wymagań odbiorcy jest jednak możliwe, jeśli przezwyciężony zostanie tradycyjny, długotrwały i kosztowny sposób współdziałania wszystkich przedsiębiorstw kooperujących na rzecz finalnej dostawy. Współczesne systemy informatyczne wspomagające zarządzanie pozwalaja z tych kooperantów stworzyć jedno wirtualne przedsiębiorstwo, tzw. przedsiębiorstwo rozszerzone. Pojęcie rozszerzonego przedsiębiorstwa wyewoluowało z takich pojęć, jak łańcuch dostaw czy łańcuch wartości, i jest tożsame z siecią przedsiębiorstw kooperujących w sposób bardziej lub mniej trwały w celu zaspokajania potrzeb wspólnych klientów finalnych ${ }^{43}$. Autonomiczność tych przedsiębiorstw mogłaby szkodzić kosztowej atrakcyjności produktu finalnego i czasowi jego dostarczania do odbiorcy, gdyby nie możliwość korzystania ze wszelkiego typu systemów ERP II. Jest to system łaczaccy zalety tradycyjnego systemu ERP pozwalającego koordynować procesy wewnątrz firmy z korzyściami związanymi z użytkowaniem Internetu, poprzez który staje się możliwe zintegrowanie zachowań wielu firm w czasie rzeczywistym ${ }^{44}$. Dzięki zastosowaniu ERP II staje się możliwe: skrócenie czasu reakcji na zapytanie ofertowe, podniesieniu profesjonalizmu wykonania oferty, zwiększenie elastyczności w formułowaniu oferty, skrócenie czasu realizacji dostawy, dostarczanie wiarygodnej informacji o dacie dostawy, zapewnienie bezpośrednich kontaktów z ludźmi zaangażowanymi w cały proces, ułatwienie identyfikacji klienta przy następnym zamówieniu, nielubienie wiedzy o dotychczasowej współpracy z odbiorca oraz możliwość odwołania się do parametrów poprzedniej dostawy ${ }^{45}$.

${ }^{42}$ Y. Yusuf et al., Agile Supply Chains Capabilities: Determinants of Competitive Objectives, „European Journal of Operational Research” 159, 2004, s. 382.

${ }^{43}$ What Is the Extended Enterprise?, http://jpfarrell.blogspot.com/2008/04/extended-enterprise.html (dostep: 15.04.2013).

${ }^{44}$ A. Amarowicz, ERP II - narodziny nowego standardu, „CEO Magazyn Top Menedżerów” 2003, luty http://ceo.cxo.pl/artykuly/29156/ERP.II.narodziny.nowego.standardu.html (dostęp: 15.04.2013)

${ }^{45}$ P. Lech, Zintegrowane systemy zarzadzania ERP/ERP II, Difin, Warszawa 2003, s. 62-63. 


\section{KONKLUZJE}

Migracja źródeł konkurencyjności na rynkach, na których są obecne współczesne przedsiębiorstwa, wymaga od nich zmiany zachowań biznesowych. Coraz krótszy czas, podczas którego można osiagnąć sukces rynkowy mierzony ponadprzeciętna efektywnością użytkowania czynników produkcji, oraz coraz bardziej zindywidualizowane wymagania klientów finalnych wykreowały idee zwinności przedsiębiorstwa.

Można postawić pytanie, czy koncepcja zwinnego przedsiębiorstwa jest nową doktryną w zarządzaniu, czy też tylko chwytną nazwą zbioru wcale nie najnowszych technik zarządzania. Jeśli doktrynę zarządzania rozumieć jako zestaw zasad, metod i technik postulowanych jako wzorcowy sposób zarządzania przedsiębiorstwem znajdującym się w zdefiniowanych uwarunkowaniach oraz dodatkowo doktrynę tę wyprowadzać z konkretnych przesłanek teoretycznych, to zapewne można mówić o wyłaniającej się koncepcji teoretycznej.

U podstaw teorii średniego zasięgu nazywanej zwinnym przedsiębiorstwem leży obserwacja o ewolucji źródeł i trwałości przewagi konkurencyjnej we współczesnej gospodarce. Teoria ma zasięg średni, ponieważ jest uzasadnieniem i zbiorem wytycznych dla kierownictw przedsiębiorstw działających w warunkach okazjonalnej możliwości kształtowania przewagi konkurencyjnej. Zmianie ulegają wówczas podstawowe problemy strategiczne, przed których rozwiązaniem stają kierownictwa przedsiębiorstw. Inny jest zatem opis strategicznej sytuacji problemowej i inne uzasadnienia teoretyczne pożądanych zachowań biznesowych.

prof. dr hab. Piotr Banaszyk Uniwersytet Ekonomiczny w Poznaniu piotr.banaszyk@ue.poznan.pl AGILE ADJUSTMENTS OF ENTERPRISES ON MARKETS
WITH AN OCCASIONAL COMPETITIVE ADVANTAGE

Summary

In this paper the relationship between a certain type of competitive conditions and the desired adjustment of company's activities is identified and characterised, followed by reconstruction of contemporary conditions of competition and a proposal of business activities best suited to these conditions. As global economy is currently dominated by so-called occasional competitive advantage, companies should implement an agile business behaviour. The conception of an agile company is a new paradigm in business management. 
Copyright of Journal of Law, Economics and Sociology is the property of Faculty of Law and Administration of Adam Mickiewicz University in Poznan and its content may not be copied or emailed to multiple sites or posted to a listserv without the copyright holder's express written permission. However, users may print, download, or email articles for individual use.

Właścicielem praw autorskich do „Ruchu Prawniczego, Ekonomicznego i Socjologicznego” jest Wydział Prawa i Administracji Uniwersytetu im. Adama Mickiewicza w Poznaniu. Zawartość czasopisma nie może być kopiowana, przesyłana do innych stron internetowych bądź zamieszczana na blogach bez pisemnej zgody wydawcy. Niemniej artykuły można drukować, kopiować lub przesyłać w formie elektronicznej na własny użytek. 